\title{
Reception of G. Rossini's Opera "Guglielmo Tell" in Russian and Soviet Musical Culture
}

\author{
Marina Raku \\ State Institute of Arts Studies \\ Moscow, Russia \\ E-mail: raku@rambler.ru
}

\begin{abstract}
Staging history of the most famous European operas on the Russian stage and especially their perception by the public is the one of the little-studied problem. In the meanwhile European opera culture and first of all its most important examples have aroused constant interest by the performers, were very popular among public attracted attention from Russian composers, journalists, critics. Archival documents, news-papers and magazine publications, epistolary and memoirs and fiction literature allow recreating reliable historical picture of the "Russian destinies" of European opera masterworks. Among "special cases" of such a reception is the last opera of Rossini, whose destiny in the Russian culture turned out to be very bizarre. It's stage appearances were influenced by censorship conditions of the Tzar Russia and ideological demands of the Soviet period. The reception process of this opera in the composers' artwork - from dramaturgic solutions to the choice of stylistic tools - is of special interest. Proposed scientific report will cover the following questions: which features of Rossini's masterpiece have influenced emergence of creative ideas of the Russian composers from Glinka to Prokofiev and Shostakovich as well as the authors of the "second row". The report's aim is to try to answer the question - why this masterpiece took such a distinctive place in the Russian culture and won the respect of Russian opera public and musical circles. This question will be investigated in the context of "Ital'yanshchina" and French "grand opéra" problems in the Russian and Soviet music.
\end{abstract}

Keywords-Rossini; "Guglielmo Tell”; French "grand opéra"; European operas on the Russian stage; the reception process; "Ital'yanshchina"; M. Glinka's "A Life for the Tzar"; the Soviet musical culture; S. Prokofiev; D. Shostakovich

\section{INTRODUCTION}

The history of the Rossini's opera "Guglielmo Tell" reception will be investigated in the context of "Ital'yanshchina" (how the passion for Italian opera in Russia is called) and French "grand opéra" problems in the Russian and Soviet music. This Rossini's opera appearance on the Russian stage was prepared by acquaintance and interest for his operas of the Italian period. The author of "Guglielmo Tell" continued to be seen as representative of Italian opera tradition. And at the same time his latest opera composition was compared to opuses by Meyerbeer, Auber and Halevy - founders of the French "grand opéra". This scores turned out to be crossroad, where two musical streams, often seen by public and critics as antagonists, have met. First stream incarnated for public supreme power of music in the opera theatre. Second stream became symbol of growing weight of drama art on the musical stage.

\section{THE RUSSIAN PREMIERE}

Because of obstacle of censorship "Guglielmo Tell" in Russia got ahead of "Robert le diable" by Meyerbeer and "La Juive" by Halevy. Only in 1838 - after nearly decade after its birth - "Guglielmo Tell" under the name of "Carl the Brave" entered Russian stage. Not only title, but also plot and the mere plot source have changed. Well-known journalist, critics and constant translator of opera libretto Raphail Mikhailovich Zotov following censorship requirements has based the opera on the plot of Walter Scott's novel "Anne of Geierstein, or The Maiden of the Mist". The novel was published in Edinburgh and in London in 1829 , it was translated in Russia in 1830 under the name of "Carl the Brave". The story in one of the most popular Walter Scott's novels takes place in the 15-th century. French King Louis XI gets ready for the war with his mortal enemy Carl the Brave. Using cunning and bribery he tries to draw into it Swiss. But at the end not war, but mystics of medieval castle and love to mysterious beauty turn out to be the main theme of Zotov's libretto.

Regardless of such serious change of the plot, opera score was first published in Russian language one year before premiere in St. Petersburg with meaningful remark "all music of the famous Rossini opera preserved" [1]. The same fact was underlined in the note about premiere in the Bolshoi Theatre of St. Petersburg on April 21, 1838. The very first review on the premier though states that "already first performance of Carl the Brave opera seemed too long and tedious to many people. As a result it was decided to introduce cuts in several places. Unfortunately, - Zotov wrote, - this severe ostracism has fallen on the best parts of the score. Amateurs were especially sorry to lose a charming chorus a-moll in Act 1 and chorus in the beginning of Act 2 . By eliminating the latter the mere musical idea was partially damaged. ... On behalf of all opera lovers we ask to return these two numbers and are willing in return to give away the most part of dances in Act 3 and Act 5" [2].

With common practice of cuts, that were introduced with no exception to all operas performed in Russian on the 
Imperial Stage of that period, this demand meant that value of this opus in the eyes of the critics was especially high. He wrote:

"Imagine not an opera, - the way you are used to understand this notion in common popular way, - e.g. not a set of arias, duets, tercets and choruses somehow connected by recitatives, not an album with motives, that are good only for Waltzes and quadrilles, but the whole universe of lofty ideas, gigantic images and musical thoughts completely new and unexpected, whole ocean of harmonies and melodies. Then you will get a very weak idea of Guglielmo Tell score. In order to fully appreciate this great creation, it is important to grasp all its beauty and perfection. We suppose that in case Rossini would not have composed neither Semiramide nor La Cenerentola or Il Barbiere di Siviglia, - nothing except for Guglielmo Tell, even then this one composition could give him inalienable right to be named the first among contemporary composers. In Guglielmo Tell we hear another human being, another Rossini. He has showed himself as a deep connoisseur of music and united northern technical style and harmony with southerly melody; freshness of thought he mixed with charm of its expression, and he knew how to expertly give opera color of terrain, warm it up with tender feeling of love to motherland, that makes pride of each Swiss. Guglielmo Tell phenomenon is very important in the history of dramatic music also because the day of its premier was the day new school was born. Founders of this school are unfairly thought to be Mayerbeer and Halevy" [3].

But the last Rossini's opera and one of the first opuses in "grande opéras" genre was outstripped on the Russian stage not only by Meyerbeer's and Halevy's creations in new genre, but also by the first Russian opera, written by pattern of this newly appeared genre of "big historical opera". We are talking about opera "A Life for the Tsar" (or "Ivan Susanin") by Mikhail Glinka here, that is traditionally seen as the beginning of Russian opera school.

\section{III. “A LIFE FOR THE TZAR" OF MiCHAIL GLINKA AS THE ROSSINI'S RECEPTION}

Although western genesis of this composition was denied during long period of time in Russian musicology, nevertheless some authors characterized it as "an attempt to combine Italian style in its most perfect manifestations with flexible French melody at the same time preserving Russian melodiousness". In his turn Richard Taruskin ascribes to the author of "A Life for the Tsar" mastery of knowing "Rossini codex" (as this set of formal methods was called by Julian Badden [4]).

When comparing "A Life for the Tsar" with "Guglielmo Tell" several fundamental similarities become evident: appeal to half-legendary and half-historical plot (story of Susanin's exploit: he enticed an enemy polish squad into swamp in order not to let them catch young Tzar. This story still has status of a legend like the story of Tell); national and religious conflict in the center of dramaturgy; accentuation of national-patriotic motives; new pleb-hero, who obtains an uncommon courage and moral perseverance; exposition of his image as coryphaeus of choir, depiction of an enemy image through collective portrait created by means of choral and dance music (Pas de trois with chorus). The last principal Glinka leads to absolute, refusing Poles in any kind of personification. Exposition schemes of both operas appear nearly identical: preparation to meet spring, expectation of wedding time, severe reminder from father-hero of necessity to postpone fest for the sake of combating invaders.

Neither Rossini nor Glinka use leitmotif dramaturgy. Nevertheless in both cases through the whole score is carried dramatic motive of "thunderstorm", presented in the form of rhetoric formula or with the help of certain timbres, or sometimes by verbal reminder: from storm episode in overture and appearance of shepherd, pursued by Austrians, - before introduction to Matilda romance and gathering of rebels on the head of mountain Ruetli.

Dramaturgy of this Rossini composition is build upon breach of idyllic topos by invasion of destructive and hostile force. Its personification becomes Austrian conquerors, but behind national conflict action of certain higher natural forces is traced. Cosmogonic character of social turmoils is a favorite thought of "big"/ "historical" French opera, that was formed before Rossini's eyes and with his direct participation. Authors of "La Muette de Portici", "Les Huguenots" and "Le prophète" have devoted themselves to prove its existence, and it is Rossini who formulates it already in the overture, which thematic material was borrowed from sketches to an unwritten opera "La Tempesta". Supreme-plot of "Guglielmo Tell", formulated in overture, comes down to a collision "peace/storm invasion/restoration of world harmony". Final Chorus of the opera - is a thanksgiving to God for saving Tell and restoring motherland idyll (again as in barcarole, that is beginning opera with "hommage an Createur"). As in the beginning in the fisherman song there is a sound of harp ambivalent image of paradise and water flows, dynamics of melodic ascent illustrates the theme of mountain altitudes.

As well as in "Guglielmo Tell", in "A Life for the Tsar" method "couleur locale" is interpreted symbolically. Motives of tempest, thunderstorm, gale occupy a significant place on the opera pages. Libretto text variegates with it starting from the very first pages with the opening chorus "During the thunderstorm and tempest". And the IV Act - opera culmination - is presented as a realm of the snowstorm. But music answers to this verbal rhetoric much less, then it happens in Rossini. Thunderstorm in its musical form indeed literally breaks out in a famous fugato in the forest (Act IV). It is forecasted long before only by orchestral tremolo, that accentuate motive of thunderstorm twice in the polish act on the corresponding words. The more noticeable against the background of musical rhetoric of thunderstorm becomes appearing arpeggio of harp in the main part of Susanin's aria "You will raise, my dawn!". Replacing rhetoric of thunderstorm, in this kind of opera contexts harp is traditionally correlated with the image of the rainbow and of the paradise. Because in Christian symbolism rainbow is a sign of reconciliation of higher forces with human being and humanity. 
One of the devoted connoisseurs of the opera "A Life for the Tsar", Russian composer and critic Alexander Serov wrote: "It is difficult for one who has eyes ... not to notice that almost all the great movement of the musical drama of our time, with all its wide horizons opening before us, is closely connected to the victories of the author of Guglielmo Tell" [5]. Probably, he also had in mind the first fundamental (opera) score of the Russian musical theater — the composition of Glinka.

\section{THE PUBLIC's INDIFFERENCE AND THE COMPOSER'S INTEREST}

Meanwhile, the destiny of Rossini's last opera on the Russian stage was not fortunate. Its resumption in the season of 1846 was just as brief as the life of the premiere performance (only two seasons in both cases). Although its return was met with glee, the delight of the Russian audience was short-lived. For instance, Zotov, who jealously tracking the fate of his creation on the pages of St.Petersburg press, wrote in 1848 of the public of "Karl the Bold": "We say "the public", although we do not know yet whether it is possible to give this title to a small number of theatre goers who gathered that evening. The lodges of the dress circle were completely empty (out of twenty-eight only two were occupied). The first eight rows of seats were hardly half filled by the audience. But those who came could be called true (opera) connoisseurs" [6].

Even later the situation did not improve. In 1850, Zotov again reports on the performance of "Karl the Brave": "It was with great sadness that we saw the extreme emptiness of the seats and could not help wondering why. The opera was so good that the most demanding dilettante would not find any drawback. ... In short, this performance was a true musical delight. It's a pity that there were so few of those who wished to try it" [7]. Based upon the reviews, in subsequent years the audience either filled the hall in the days of the show "Karl the Brave" or didn't pay it much attention. As a result, the play rarely appeared on the poster.

With the onset of the Soviet era, Rossini's opera practically got out of the repertoire. For the entire pre-war period it was staged only once - in Leningrad in 1932 in a new translation and under the original name - and did not become a special event. But the traces of the influence of "Guglielmo Tell" were reflected in the Soviet musical theater through following the example of "A Life for the Tsar". In 1939 the rehash of "A Life for the Tsar" to "Ivan Susanin" appeared on the Soviet stage. The first Glinka's opera now served as an officially appointed model for the creation of the "soviet classical opera", as formulated by Joseph Stalin in a task to composers and theaters.

Two operas in 1939 — "Semjon Kotko" by Sergey Prokofiev and "Into the Storm" by Tikhon Khrennikov reproduce in the exposition a similar configuration of the motifs of the plot: the peaceful life of the villagers is disturbed by the invasion of the enemy. For instance, in the "Semjon Kotko" this role played by the interventionists. Along with the topoi of the "peaceful life of the villagers" and the "military thunderstorm", the topos of the "village wedding", which is postponed due to the war, is also in demand. In Khrennikov's opera, this resemblance to the operas of Glinka and Rossini is supplemented by the introduction of the dramatic motif of the thunderstorm in the scene of the death of the main character.

By this time in the auditory experience of the new generation Rossini's opera itself reduced to a famous overture, which, incidentally, was among the main hits of academic music. For example, in the cult-comedy "VolgaVolga" (1938) where a provincial bureaucrat, who had denied the residents of a small town in Siberia government support for their amateur art performances, was literally cornered by a demonstration of their various talents.

In 1942, "Guglielmo Tell" was staged at the Bolshoi Theater, which was in evacuation in Kuibyshev (now the city of Samara) at that time. The production was timed to coincide with the 25th anniversary of the October Socialist Revolution. The meaning of the appeal to this name was frankly propagandistic: the opera was considered in the comments to the production and reviews as a symbol of patriotism, a direct allusion to the struggle against fascism sharp political satire sounded in the "dance of the marching Landsknechts", with their mechanical, puppet movements. One of the reviewers of the production was Dmitri Shostakovich, who was also in evacuation in Kuibyshev, where his 7th "Leningrad" Symphony, written on a similar theme, was soon premiered. He and writer Valentin Katajev wrote in the newspaper "Pravda" (1942, 7 November) about the production: "The opera sounds fresh and inspirational in the world, shaken by the unheard-of titanic struggle of everything fair and reasonable against the gloomy forces of bloody fascism and tyranny".

It is Shostakovich to whom the last significant reception of "Guglielmo Tell" in Russia is linked. Namely, the citation of the final section of the overture to the opera that plays a significant role in the composer's 15th Symphony: it appears five times in the first part - Allegretto. The meaning of the appearance of that (as well as other citations) cannot be deciphered. Shostakovich did not furnish the clue to it, saying only: "I myself do not know what are these quotes for, but I could not help making these quotations, just that". One way or another, the quotation from Rossini became one of the musical symbols of the last symphony of the composer: his final essay on life and death.

"Guglielmo Tell" has always enjoyed the respect of the Russian public. However only a few of its representatives shared the love of this opera of Rossini. Nevertheless, today their names sound impressive to us: Alexander Pushkin and Michail Glinka, Ivan Turgenev and Michail SaltykovShchedrin, Fjodor Dostoevsky and Dmitry Shostakovich....

\section{CONCLUSION}

So, the fate of this opera in Russia was surprisingly unlike that of the other works of the Italian or French opera schools, to which Russian audience never disputed each other's love and respect. 


\section{REFERENCES}

[1] Carl the Brave: Grand opera in 4 acts: the Plot is borrowed from the novel by Walter Scott with the abridgement of all music of the famous opera "Guglielmo Tell", composed by Rossini. SPb.: I. Glazunov i Co. Printing House, 1837 [in Russian].

[2] [R.M. Zotov] Bolshoi Theatre // Severnaya pchela, 17 May (No. 117), 1838, p. 467 [in Russian].

[3] Ibid, p. 465.

[4] Budden J. The Operas of Verdi: 3 Vol. Rev. ed. New York, 1992.

[5] Serov A. H. Rossini. Critical essays // Serov A.H. Collected articles, t. 1, M. - L., 1950, p. 152. [in Russian].

[6] Zotov R.M. Feuilleton. Theatre chronicles. Benefit performance of Coletti // Severnaya pchela, 1848, 13 December (№ 280), p. 1118 [in Russian].

[7] Zotov R.M. Pchelka. Theatre chronicles // Severnaya pchela, 1850, 25 November (No. 263), p. 1049 [in Russian]. 